\title{
Determination of Aluminum Concentration in Molten Zinc by the E.M.F. Method Using Zirconia Solid Electrolyte
}

\author{
Shigeo MATSUBARA, Tatsuhiro TSUTAE, Kazunari NAKAMOTO, Yusuke HIROSE, ${ }^{1)}$ \\ Iwao KATAYAMA ${ }^{2)}$ and Takamichi IIDA ${ }^{2)}$
}

Forming Technology Development Laboratories, Nisshin Steel Co., Ltd., Tsurumachi, Amagasaki, Hyogo-ken, 660 Japan.

1) New Materials Research Laboratories, Nisshin Steel Co., Ltd., Koyashinmachi, Ichikawa, Chiba-ken, $272-01$ Japan.

2) Faculty of Engineering, Osaka University, Yamadaoka, Suita, Osaka, 565 Japan.

(Received on October 26, 1994; accepted in final form on January 27, 1995)

Control of the dissolved aluminum concentration in a hot dip galvanizing bath is of great importance for producing galvannealed steel sheets. Since aluminum has much greater affinity for oxygen than zinc, the oxygen potential of $\mathrm{Zn}-\mathrm{Al}-\mathrm{O}$ bath may be determined only by the following equilibrium reaction; $\mathrm{Al}_{2} \mathrm{O}_{3}(\mathrm{~s})=2 \mathrm{Al}$ (in $\left.\mathrm{Zn}\right)+3 \underline{O}$ (in $\mathrm{Zn}$ ) when the aluminum concentration in the bath is relatively low. Aluminum sensor based on the emf method using the zirconia solid electrolyte has been devised by utilizing the above equilibrium relation.

In this paper, emf measurements have been carried out in $\mathrm{Zn}-\mathrm{Al}-\mathrm{O}$ baths having aluminum concentration of $0.02-0.50$ mass \% under an air atmosphere by using some of the most appropriate combinations of zirconia solid electrolyte and liquid reference electrode for $\mathrm{Zn}-\mathrm{O}$ baths.

From the analysis of such emf values at temperatures between $450-500^{\circ} \mathrm{C}$, the following relationships between aluminum concentration and cell emf for two reference electrodes were obtained;

$$
\begin{array}{lll}
E / \mathrm{mV}=57.19 \ln [\mathrm{Al}] / \mathrm{mass} \%+506.4, & 0.02 \leqq[\mathrm{Al}] / \mathrm{mass} \% \leqq 0.30 & \left(\ln -\mathrm{In}_{2} \mathrm{O}_{3} \text { as ref. electrode }\right) \\
E / \mathrm{mV}=68.27 \ln [\mathrm{Al}] / \mathrm{mass} \%+270.4, & 0.05 \leqq[\mathrm{Al}] / \mathrm{mass} \% \leqq 0.20(\mathrm{Zn}-\mathrm{ZnO} \text { as ref. electrode })
\end{array}
$$

The external $A C$ voltage applied on these sensors immediately after immersion into the bath showed to be effective to their responsibility and stability. The emf measurements were also carried out in $\mathrm{Zn}-\mathrm{Mn}-\mathrm{O}$ and $\mathrm{Zn}-\mathrm{Cr}-\mathrm{O}$ baths, respectively, and it has been ascertained that the sensors work much better in these baths, even though the partial oxygen pressure $P_{\mathrm{O}_{2}}$ of the bath is as low as $10^{-40} \mathrm{~Pa}$ at $450^{\circ} \mathrm{C}$. The possibility of the present aluminum sensor has been ascertained experimentally.

KEY WORDS: hot dip galvanizing; aluminum sensor; zirconia solid electrolyte; zirconia sensor; reference electrode; dissolved aluminum; dissolved oxygen.

\section{Introduction}

Control of the dissolved aluminum concentration in a hot dip galvanizing bath is of great importance for producing galvannealed steel sheets. ${ }^{1-3)}$ Nowadays, analysis of the specimen sampled from the bath by the fluorescence X-ray method has become popular to determine the aluminum concentration in the bath. However, this instrumental method takes a relatively long time and gives the concentration of total aluminum instead of dissolved aluminum which has a major influence on the alloying performance of iron with zinc.

In order to get a quality controlled galvannealed layer, a rapid and accurate method for determining this dissolved aluminum concentration has been required.

The authors have tried to apply the emf method using zirconia solid electrolyte, ${ }^{4-8)}$ which has been used to measure the activity of oxygen in molten metals or alloys. ${ }^{9,10)}$ The method is based on the principle described below: Since aluminum has much greater affinity for oxygen than zinc, the oxygen potential of $\mathrm{Zn}-\mathrm{Al}-\mathrm{O}$ bath may be determined only by the following equilibrium reaction; $\mathrm{Al}_{2} \mathrm{O}_{3}(\mathrm{~s})=2 \mathrm{Al}$ (in $\left.\mathrm{Zn}\right)+3 \underline{\mathrm{O}}$ (in $\mathrm{Zn}$ ) when the aluminum concentration in the bath is relatively low. Aluminum sensor with the zirconia solid electrolyte has been devised by utilizing the above equilibrium relation, i.e., from the oxygen potential of the bath, aluminum concentration is derived indirectly.

In this paper, emf measurements have been carried out in a zinc bath opened to the air atmosphere by using zirconia solid electrolytes with various stabilizer and liquid reference electrodes in order to determine the optimum cell construction for the sensor. Then, emf measurements have been carried out in $\mathrm{Zn}-\mathrm{Al}-\mathrm{O}$ baths having aluminum concentration of $0.02-0.50 \mathrm{mass} \%$ under an air atmosphere by using some of the most appropriate cell constructions determined by the above emf measurements in $\mathrm{Zn}-\mathrm{O}$ baths. Also, in some cases 
the external $\mathrm{AC}$ voltage was applied on these sensors immediately after immersion into the bath in order to improve the initial response of the sensor.

Furthermore, in order to investigate the lowest limit of partial oxygen pressure which can be detected by the present zirconia oxygen sensor, pure manganese or chrominum has been employed as a deoxidizer for molten zinc, and the emf measurements were carried out in $\mathrm{Zn}-\mathrm{Mn}-\mathrm{O}$ and $\mathrm{Zn}-\mathrm{Cr}-\mathrm{O}$ baths, respectively.

It has been ascertained that the sensors work much better in these baths, even though the partial oxygen pressure $P_{\mathrm{O}_{2}}$ of the bath is as low as $10^{-40} \mathrm{~Pa}$ at $450^{\circ} \mathrm{C}$.

\section{Experimental Procedures}

\subsection{Experimental Principles}

When the following oxygen concentration cell $(-) P_{\mathrm{O}_{2}}(\mathrm{I})\left|\mathrm{ZrO}_{2}(+\mathrm{MO})\right| P_{\mathrm{O}_{2}}(\mathrm{II})(+)$ is constructed using a stabilized zirconia as solid electrolyte, the emf of the cell is represented by the following equation.

$$
E=(1 / 4 F) \int_{\mathrm{P}_{2}(\mathrm{I})}^{P_{\mathrm{O}_{2}}(\mathrm{II})} t_{\text {ion }} d \mu_{\mathrm{O}_{2}}
$$

Assuming that the transference number of oxygen in the solid electrolyte is nearly equal to unity, Eq. (1) becomes

$$
E=(R T / 4 F) \ln \left(P_{\mathrm{O}_{2}}(\mathrm{II}) / P_{\mathrm{O}_{2}}(\mathrm{I})\right)
$$

where $E$ is the emf of cell, $R$, the gas constant, $T$, the thermodynamic temperature, $F$, the Faraday constant, $P_{\mathrm{O}_{2}}$, oxygen pressure, and $\mu_{\mathrm{O}_{2}}$, chemical potential of oxygen.

When the mixture of $\operatorname{In}, \operatorname{In}_{2} \mathrm{O}_{3}$ was used as a reference electrode, $P_{\mathrm{O}_{2}}$ (II) at a given temperature can be calculated from both Eqs. (3) ${ }^{11)}$ and (4).

$$
\Delta G^{\circ}\left(\operatorname{In}_{2} \mathrm{O}_{3}\right) / \mathrm{J} \mathrm{mol}^{-1}=-916560+318.3 T / \mathrm{K},
$$$$
(959-1284 \mathrm{~K})
$$

$$
\Delta G^{\circ}\left(\operatorname{In}_{2} \mathrm{O}_{3}\right)=-R T \ln \left(1 / P_{\mathrm{O}_{2}}(\mathrm{II})^{3 / 2}\right)
$$

On the other hand, it is known that $\mathrm{Zn}-\mathrm{ZnO}$ equilibrium is easily established in a molten zinc bath which is open to the air atmosphere. Therefore, $P_{\mathrm{O}_{2}}(\mathrm{I})$ at a given temperature can be calculated in a similar way by Eqs. (5) ${ }^{11)}$ and (6).

$$
\Delta G^{\circ}(\mathrm{ZnO}) / \mathrm{J} \mathrm{mol}^{-1}=-354550+107.8 T / \mathrm{K},
$$$$
(843-1067 \mathrm{~K})
$$

$$
\Delta G^{\circ}(\mathrm{ZnO})=-R T \ln \left(1 / P_{\mathrm{O}_{2}}(\mathrm{I})^{1 / 2}\right)
$$

By substituting $P_{\mathrm{O}_{2}}(\mathrm{I})$ and $P_{\mathrm{O}_{2}}$ (II) in Eq. (2), the emf of cell $E$ is obtained as a function of the temperature and is represented by Eq. (7).

$$
E_{\text {In }} / \mathrm{mV}=254.1-0.0087 T / \mathrm{K}
$$

The emf of cell with other reference electrodes can be obtained by the same calculation procedure mentioned above.

\subsection{Construction of Zirconia Solid Electrolyte Cell}

The schematic representation of the experimental assembly is shown in Fig. 1. Molten zinc baths were pre-

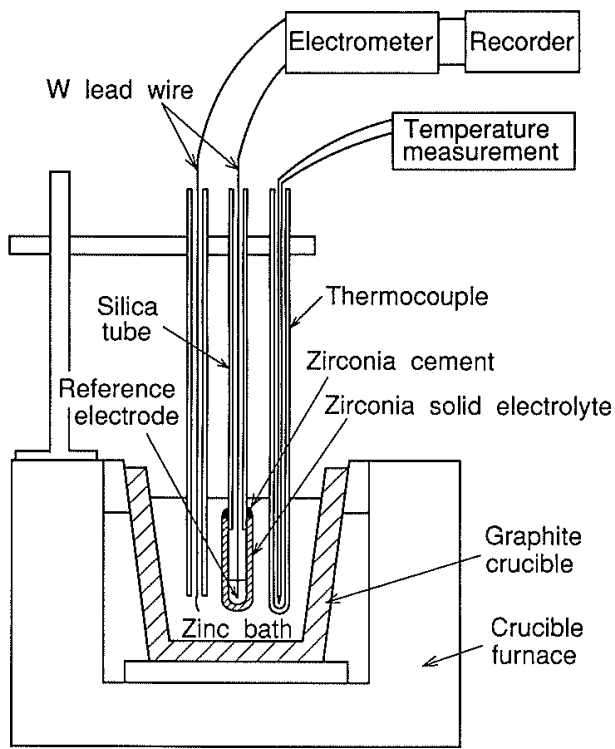

Fig. 1. Schematic representation of the experimental assembly.

pared by melting the zinc ingots of 99.99 mass \% purity in the graphite crucible in the air atmosphere. $\mathrm{Zn}-\mathrm{Al}$ baths were obtained by melting the 99.99 mass $\%$ aluminum plate in $0.1 \mathrm{~mm}$ thickness in the above mentioned pure zinc bath by stirring the bath with an alumina rod. $\mathrm{Zn}-\mathrm{Mn}$ baths or $\mathrm{Zn}-\mathrm{Cr}$ baths were obtained similarly using pure manganese or pure chromium lamps, respectively.

In some experimental runs, the possibility of reaction between oxygen in molten zinc and graphite was checked by using an alumina crucible instead of a graphite crucible.

Zirconia solid electrolytes which can be used as an oxygen sensor and available from commercial products are for example $\mathrm{ZrO}_{2}\left(+6-8 \mathrm{~mol}_{0} \% \mathrm{Y}_{2} \mathrm{O}_{3}\right), \mathrm{ZrO}_{2}(+9-11$ mol\% $\mathrm{MgO})$ and $\mathrm{ZrO}_{2}(+11-15 \mathrm{~mol} \% \mathrm{CaO})$. Besides a conventional type (ZR-type), newly developed high purity type (YSZ-type) was used as $\mathrm{ZrO}_{2}(+8 \mathrm{~mol} \%$ $\mathrm{Y}_{2} \mathrm{O}_{3}$ ).

Mixture of In (melting point: $\left.157^{\circ} \mathrm{C}\right), \mathrm{Zn}\left(420^{\circ} \mathrm{C}\right), \mathrm{Bi}$ $\left(272^{\circ} \mathrm{C}\right), \mathrm{Sn}\left(232^{\circ} \mathrm{C}\right)$ or $\mathrm{Ga}\left(30^{\circ} \mathrm{C}\right)$ and their respective oxides were chosen as the reference electrode material in view of the response and stability of cell.

In, $\mathrm{In}_{2} \mathrm{O}_{3}$ electrode was prepared by mixing In $(99.99$ mass $\%$ purity) and $\mathrm{In}_{2} \mathrm{O}_{3}$ powder reagent (99.99 mass $\%$ purity) in a weight ratio of $10: 1$ put into the above mentioned zirconia crucible produced by Nikkato Co. Ltd. $\mathrm{Zn}, \mathrm{ZnO}$ and the other electrodes were prepared by a similar method described above. A tungsten wire of 99.97 mass \% purity was used as a lead wire for both working and reference electrode because it is known to be quite stable for the corresponding molten metals below $600^{\circ} \mathrm{C.}^{12)}$

\subsection{EMF Measurement of Cell}

Experimental procedures are as follows. $K$ thermocouple for the bath temperature measurement and a lead wire for working electrode were preliminary immersed into the center of the bath at a given depth. A zirconia 
solid electrolyte crucible was heated at the neighborhood of the bath temperature for about $10 \mathrm{~min}$ in the preheating furnace exposed to the air atmosphere before immersion into the bath. The emf of cell and the bath temperature around the zirconia solid electrolyte crucible were recorded with the aid of a pen-recorder by way of an electrometer having an internal impedance of $10^{11} \Omega$. These data were simultaneously memorized in an IC memory card. Such an operation enabled the use of personal computer to edit or analyze the data efficiently and to draw the emf $v s$. time graph easily after completing a series of experiments.

In some experiments when the external $\mathrm{AC}$ voltage was applied on the zirconia solid electrolyte cell, a function generator (TOA Electronics Ltd., FS-2121) was utilized. The external AC voltage was applied on the electrolyte cell immediately after immersion into the bath for a given period. Then, the measurement of cell emf was started by broking the curcuit for external application.

\subsection{Analysis of the Bath}

After the cell emf reached to an equilibrium value, specimens for chemical analysis were sampled from the bath using a silica tube equipped with a suction syringe at its end. The specimen was cut off about $1 \mathrm{~g}$ and silica tips remained at its surface were removed. The specimen was then dissolved in $6 \mathrm{~N} \mathrm{NHO}_{3}$ and its solution was submitted to the I.C.P. spectrometry. The analysis was carried out on $\mathrm{Al}, \mathrm{Fe}, \mathrm{Pb}, \mathrm{Mn}, \mathrm{Cr}, \mathrm{Cd}, \mathrm{Sn}, \mathrm{Cu}$ and $\mathrm{Si}$ in view of both the use of graphite crucible for retaining the melt and minor impurity elements contained in zinc ingot or additive materials.

\section{Experimental Results and Discussion}

\subsection{Cell Construction for Molten Zinc}

In order to determine the optimum cell construction for the present sensor, emf measurements were carried out at first in a pure zinc bath melted in the air atmosphere by using the combination of zirconia solid electrolytes and liquid reference electrodes shown in Table 1. The emf curve of cell(III) with $\mathrm{In}, \operatorname{In}_{2} \mathrm{O}_{3}$ reference electrode is shown in Fig. 2. The cell responds quickly and shows relatively stable emf which agrees fairly well with the value calculated by Eq. (7). In the cases of cell(IV) with $\mathrm{Zn}, \mathrm{ZnO}$ reference electrode and cell(V) with $\mathrm{Bi}, \mathrm{Bi}_{2} \mathrm{O}_{3}$ reference electrode, the stable emfs were also obtained within $180 \mathrm{~s}$ after the immersion of sensor into the bath as shown in Fig. 2.

On the contrary, in the case of zirconia solid electrolytes stabilized with $\mathrm{MgO}$ (cell(I)), the stable emf was not obtained through a series of emf measurements. When zirconia solid electrolytes stabilized with $\mathrm{CaO}$ (cell(II)) were used, the cell showed emfs which were in the vicinity of calculated emf value. However, the initial response and stability of cell as well as the reproducibility of cell emf obtained by these electrolytes were evidently inferior to those obtained by $\mathrm{Y}_{2} \mathrm{O}_{3}$ stabilized zirconia solid electrolytes. It was therefore confirmed that the $\mathrm{Y}_{2} \mathrm{O}_{3}$ stabilized zirconia solid electrolytes were most
Table 1. Summary of the experimental results.

\begin{tabular}{cccc}
\hline Cell construction & $\begin{array}{c}\text { Respon- Sta- } \\
\text { sibility }\end{array}$ & $\begin{array}{c}\text { Electrical } \\
\text { bilty }\end{array}$ & $\begin{array}{c}\mathrm{k} \Omega \\
\text { resistivity }\end{array}$ \\
\hline (I) $\underline{\mathrm{O}}$ in $\mathrm{Zn}\left|\mathrm{ZrO}_{2}(+\mathrm{MgO})\right| \mathrm{In}, \mathrm{In}_{2} \mathrm{O}_{3}$ & $\times$ & $\times$ & $50-100$ \\
(II) $\underline{\mathrm{O}}$ in $\mathrm{Zn}\left|\mathrm{ZrO}_{2}(+\mathrm{CaO})\right| \mathrm{In}, \mathrm{In}_{2} \mathrm{O}_{3}$ & $\triangle$ & $\triangle$ & $1-3$ \\
(III) $\underline{\mathrm{O}}$ in $\mathrm{Zn}\left|\mathrm{ZrO}_{2}\left(+\mathrm{Y}_{2} \mathrm{O}_{3}\right)\right| \mathrm{In}, \mathrm{In}_{2} \mathrm{O}_{3}$ & $\mathrm{O}$ & $\bigcirc$ & $<1$ \\
(IV) $\underline{\mathrm{O}}$ in $\mathrm{Zn}\left|\mathrm{ZrO}_{2}\left(+\mathrm{Y}_{2} \mathrm{O}_{3}\right)\right| \mathrm{Zn}, \mathrm{ZnO}$ & $\bigcirc$ & $\bigcirc$ & $<1$ \\
(V) $\underline{\mathrm{O}}$ in $\mathrm{Zn}\left|\mathrm{ZrO}_{2}\left(+\mathrm{Y}_{2} \mathrm{O}_{3}\right)\right| \mathrm{Bi}, \mathrm{Bi}_{2} \mathrm{O}_{3}$ & $\bigcirc$ & $\bigcirc$ & $2-20$ \\
(VI) $\underline{\mathrm{O}}$ in $\mathrm{Zn}\left|\mathrm{ZrO}_{2}\left(+\mathrm{Y}_{2} \mathrm{O}_{3}\right)\right| \mathrm{Sn}, \mathrm{SnO}_{2}$ & $\times$ & $\times$ & $>1000$ \\
(VII) $\underline{\mathrm{O}}$ in $\mathrm{Zn}\left|\mathrm{ZrO}_{2}\left(+\mathrm{Y}_{2} \mathrm{O}_{3}\right)\right| \mathrm{Ga}, \mathrm{Ga}_{2} \mathrm{O}_{3}$ & $\times$ & $\times$ & $>1000$ \\
\hline
\end{tabular}

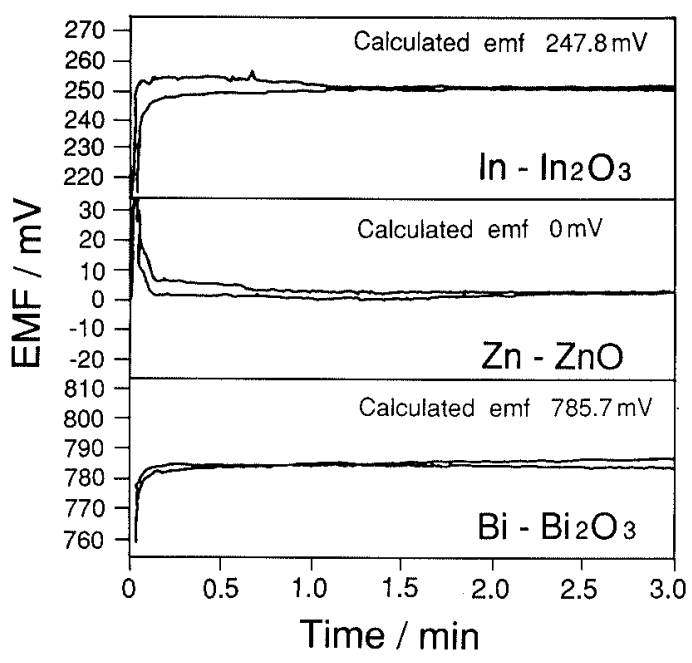

Fig. 2. Example of the emf curves of cells: $\mathrm{Zn}, \mathrm{ZnO} / \mathrm{ZrO}$ $\left(+8 \mathrm{~mol} \% \mathrm{Y}_{2} \mathrm{O}_{3}\right)\left|\mathrm{In}_{2} \mathrm{In}_{2} \mathrm{O}_{3} ; \mathrm{Zn}, \mathrm{ZnO}\right| \mathrm{ZrO}_{2}(+8 \mathrm{~mol} \%$ $\left.\mathrm{Y}_{2} \mathrm{O}_{3}\right) \mid \mathrm{Zn}, \mathrm{ZnO}$ and $\mathrm{Zn}, \mathrm{ZnO} \mid \mathrm{ZrO}_{2}(+8 \mathrm{~mol} \%$ $\left.\mathrm{Y}_{2} \mathrm{O}_{3}\right) \mid \mathrm{Bi}, \mathrm{Bi}_{2} \mathrm{O}_{3}$

suitable for the measurement of oxygen potential at low temperature.

Subsequently, the possibility of other reference electrodes were investigated using the $\mathrm{Y}_{2} \mathrm{O}_{3}$ stabilized zirconia solid electrolyte. In the case of $\mathrm{Sn}, \mathrm{SnO}_{2}$ reference electrode (cell(VI)) as well as $\mathrm{Ga}, \mathrm{Ga}_{2} \mathrm{O}_{3}$ reference electrode (cell(VII)), the electrical resistivity of cell was much larger than that of cell(III)-(V). This may be due to the difference in the morphology of oxide in the liquid reference electrode, however no reliable data are available to explain this phenomenon.

As summarized in Table 1, cell(III) and cell(IV) are considered to be the optimum cell construction for the present aluminum sensor. Therefore, these two types of cell were adopted for the emf measurement in $\mathrm{Zn}-\mathrm{Al}$ baths.

\subsection{EMF Measurements in $\mathrm{Zn-Al}$ Baths}

Before emf measurements, variation of the aluminum concentration in $\mathrm{Zn}-\mathrm{Al}$ baths with time was checked by the analytical method mentioned in Sec. 2.3. Although the $\mathrm{Zn}-\mathrm{Al}$ bath is open to the air atmosphere, it was confirmed that the aluminum concentration in the bath was kept nearly constant for relatively long periods as shown in Fig. 3. Analysis of the present $\mathrm{Zn}-\mathrm{Al}$ baths also showed that the summation of the concentration of impurity elements was less than 0.01 mass $\%$. 


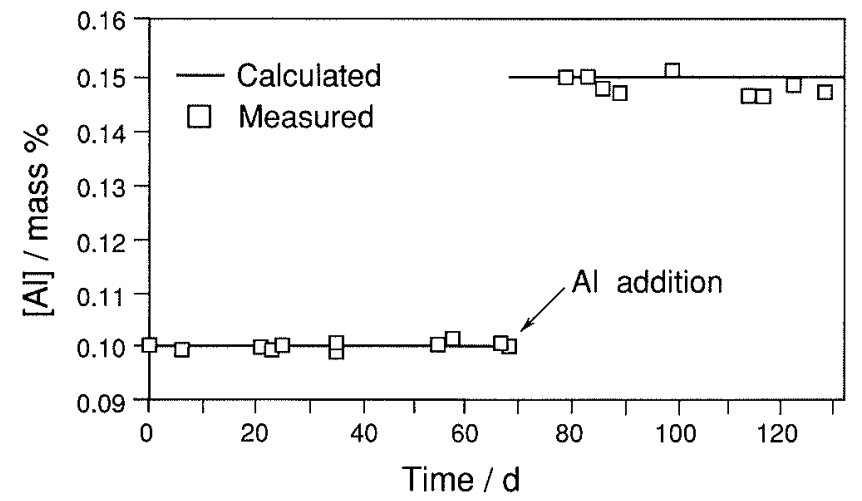

Fig. 3. Variation of the aluminum concentration in $\mathrm{Zn}-\mathrm{Al}-\mathrm{O}$ bath with time.

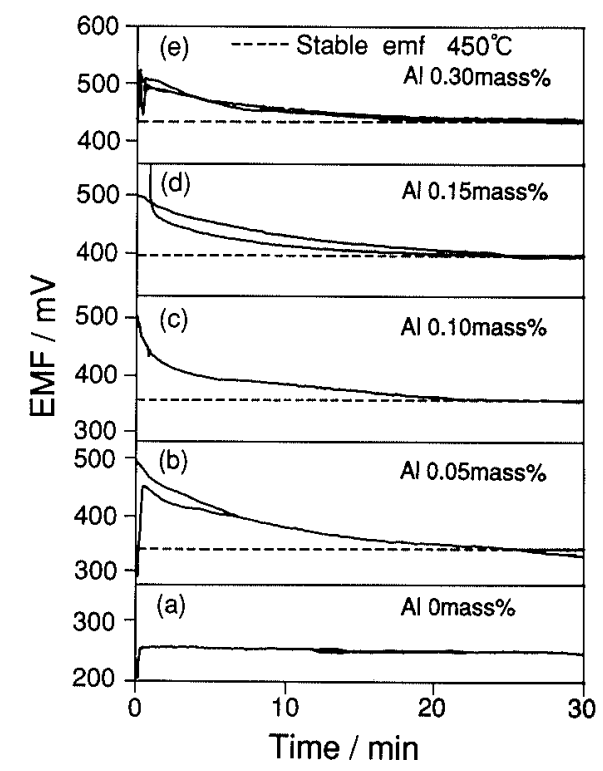

Fig. 4. Variations of cell emf with aluminum concentration and time at $450^{\circ} \mathrm{C}\left(\mathrm{In}-\mathrm{In}_{2} \mathrm{O}_{3}\right.$ ref. electrode).

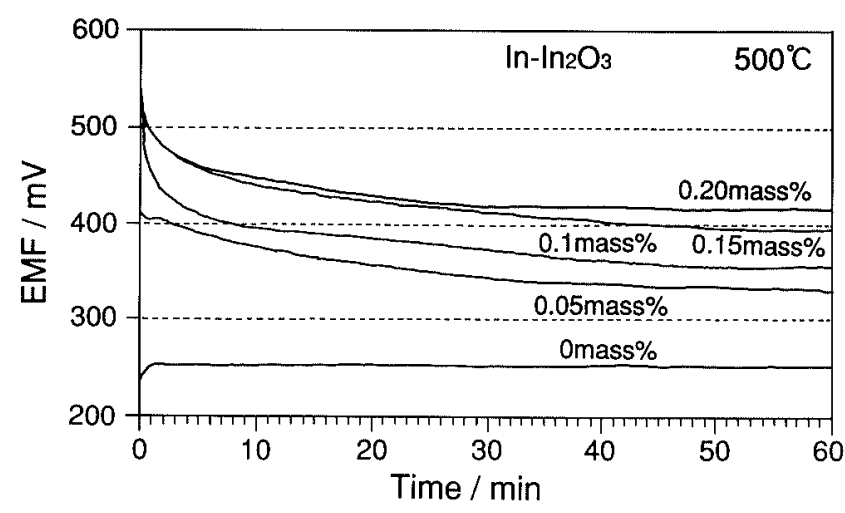

Fig. 5. Variations of cell emf with aluminum concentration and time at $500^{\circ} \mathrm{C}\left(\mathrm{In}-\mathrm{In}_{2} \mathrm{O}_{3}\right.$ ref. electrode).

Examples of emf curves of cell with $\operatorname{In}_{1} \operatorname{In}_{2} \mathrm{O}_{3}$ reference electrode are shown in Fig. 4. As shown in Figs. 4(b)-4(e), the initial response of cell in the molten zinc baths containing aluminum is inferior to that in a pure zinc bath. It took more than $20 \mathrm{~min}$ for these cells to reach a steady emf. The cell showed a comparatively steady emf, the variation of which was less than $1 \mathrm{mV}$ for 5-15 min (this was regarded as a steady emf), however

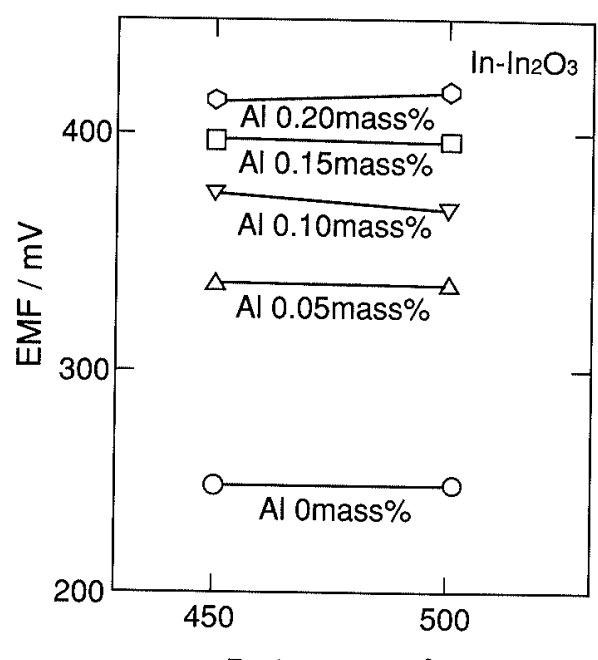

Bath temp. $/{ }^{\circ} \mathrm{C}$

Fig. 6. Temperature dependence of the emf of cell: $(-) \mathrm{W} \mid \mathrm{O}$ in $(\mathrm{Zn}-\mathrm{Al})\left|\mathrm{ZrO}_{2}+8 \mathrm{~mol} \% \mathrm{Y}_{2} \mathrm{O}_{3}\right| \mathrm{In}, \mathrm{In}_{2} \mathrm{O}_{3} \mid \mathrm{W}(+)$.

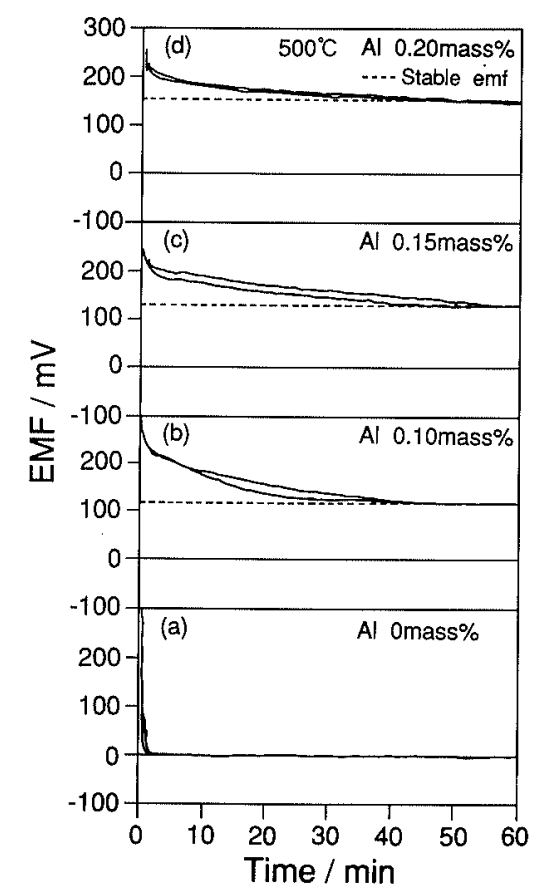

Fig. 7. Variations of cell emf with aluminum concentration and time at $500^{\circ} \mathrm{C}(\mathrm{Zn}-\mathrm{ZnO}$ ref. electrode).

the cell emf decreased gradually with the lapse of time. The scatter of cell emf $\sigma$ amounted to about $15 \mathrm{mV}$ under the same experimental conditions even though the cells showed stable emfs for a short period.

Subsequently, examples of emf curves of cell with In, $\mathrm{In}_{2} \mathrm{O}_{3}$ reference electrode at $500^{\circ} \mathrm{C}$ are shown in Fig. 5 . Stable emfs of cells in this case increased with an increase in aluminum concentration in the bath similarly as the case in $450^{\circ} \mathrm{C}$. The difference in the initial response and stability of cell between two temperatures does not seem to be significant. Figure 6 shows the emf of cell with In, $\mathrm{In}_{2} \mathrm{O}_{3}$ reference electrode as a function of temperature. These values were obtained from several different experimental runs, respectively. It is obvious from Fig. 6 that the cell emf rarely depends on the temperature. This result is in good agreement in the result that the tem- 
perature dependence of cell emf obtained in a pure zinc bath was small. In the case of an alumina crucible, nearly the same results were obtained as those in the case of a graphite crucible. This suggests that there is little possibility of reaction between the graphite and the oxygen in the bath.

Examples of emf curves of cell with $\mathrm{Zn}, \mathrm{ZnO}$ reference electrode are depicted in Fig. 7. In this case, stable emfs of cells were found to increase with an increase in the aluminum concentration in the bath, too.

\subsection{Effect of Application of External AC Voltage}

A trial to apply the external AC voltage of sine waves on the sensor immediately after immersion into the bath was made to improve the performance of the present aluminum sensor. The initial response and stability of cell were remarkably improved in some cases of $\mathrm{Zn}, \mathrm{ZnO}$ reference electrode. Similar effect was confirmed in the case of $\mathrm{In}, \mathrm{In}_{2} \mathrm{O}_{3}$ reference electrode.

The effect of the voltage or frequency of external AC voltage upon these performances was investigated using In, $\mathrm{In}_{2} \mathrm{O}_{3}$ reference electrode. Figure 8 shows the effect of voltage on the initial response of the present sensor. It was found that the higher the level of applied voltage, the faster the initial response was. The fluctuation in cell emf in steady state was decreased with an increase in the applied voltage as shown in Fig. 9.

On the other hand, concerning the effect of the fre-

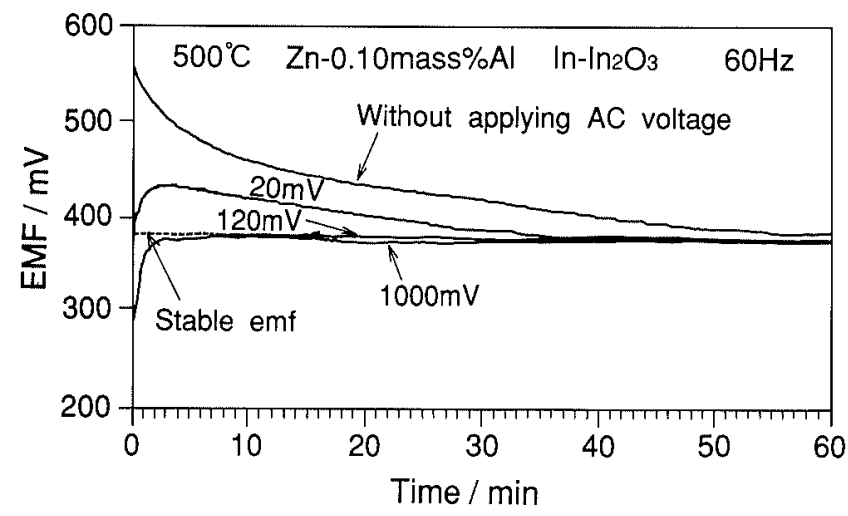

Fig. 8. Effect of the external AC voltage applied on zirconia solid electrolyte cell upon the emf curves of cell: $\underline{O}$ in $(\mathrm{Zn}-0.1$ mass $\% \mathrm{Al})\left|\mathrm{ZrO}_{2}+8 \mathrm{~mol}_{2} \mathrm{Y}_{2} \mathrm{O}_{3}\right| \mathrm{In}, \mathrm{In}_{2} \mathrm{O}_{3}$.

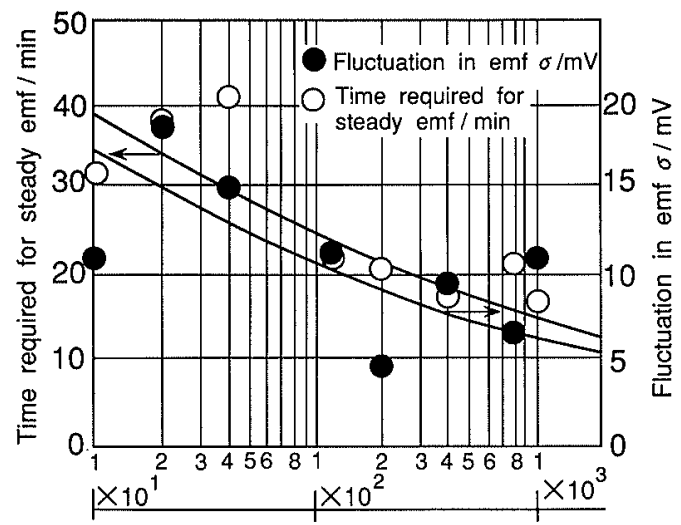

External AC voltage applied / $\mathrm{mV}$

Fig. 9. Effect of the external $\mathrm{AC}$ voltage applied upon time required for steady emf and fluctuation in emf quency of external AC voltage applied upon the initial response of cell, the response time becomes shorter at the frequency between $10-400 \mathrm{~Hz}$.

The application of external AC voltage was more effective to the YSZ-type solid electrolyte than that of ZR-type. This may be attributed to the grain size or the content of impurities in solid electrolyte. However, the mechanism of this effect of external AC voltage application has not been clarified.

\subsection{Relationship between Additive Concentration and Cell Emf}

Figure 10 shows relationships between aluminum concentration and cell emf for two reference electrode, i.e., In, $\mathrm{In}_{2} \mathrm{O}_{3}$ and $\mathrm{Zn}, \mathrm{ZnO}$ obtained by the experiments mentioned above. The least mean squares regression analysis of the emf data suggested that cell emfs for both reference electrodes linearly increase with an increase in the logarithm of aluminum concentration as represented by Eqs. (8) and (9).

$$
\begin{gathered}
\mathrm{In}, \mathrm{In}_{2} \mathrm{O}_{3}: E / \mathrm{mV}=57.19 \ln [\mathrm{Al}] / \mathrm{mass} \%+506.4 \\
0.02 \leqq[\mathrm{Al}] / \mathrm{mass} \% \leqq 0.3, \quad 450^{\circ} \mathrm{C} \ldots \ldots \ldots . \\
\mathrm{Zn}, \mathrm{ZnO}: E / \mathrm{mV}=68.27 \ln [\mathrm{Al}] / \mathrm{mass} \%+270.4 \\
0.05 \leqq[\mathrm{Al}] / \mathrm{mass} \% \leqq 0.2, \quad 500^{\circ} \mathrm{C} \ldots \ldots \ldots \ldots . .
\end{gathered}
$$

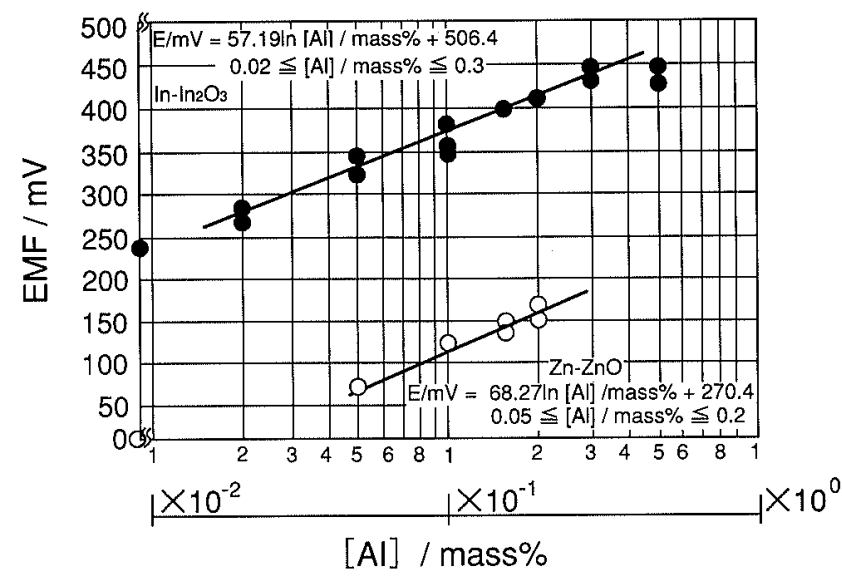

Fig. 10. Relationship between aluminum concentration in $\mathrm{Zn}-\mathrm{Al}$ baths and steady emf.

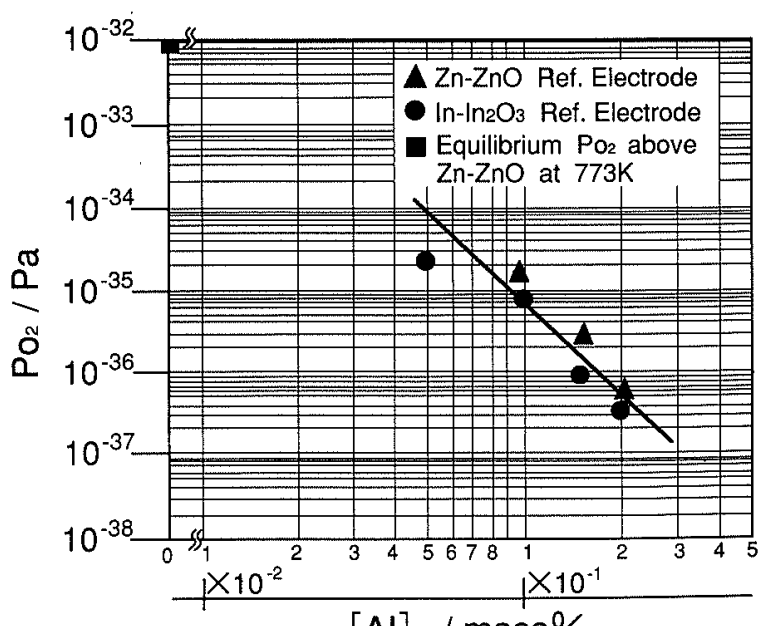

[Al] / mass $\%$

Fig. 11. Effect of aluminum dissolved upon the oxygen potential of $\mathrm{Zn}-\mathrm{Al}$ baths. 
To judge the validity of these measurements, the oxygen pressure $P_{\mathrm{O}_{2}}$ in $\mathrm{Zn}-\mathrm{Al}$ baths was calculated by the following procedures using emf data for both reference electrodes. From Nernst's equation represented by Eqs. (2) to (4), the oxygen pressure at the working electrode $P_{\mathrm{O}_{2}}$ (II) can be obtained by substituting the values of $E$ and $T$ into these equations. Calculated values of $P_{\mathrm{O}_{2}}$ (II) were plotted against the dissolved aluminum concentration represented by Eqs. (8) and (9), respectively. As a result values of $P_{\mathrm{O}_{2}}$ (II) for both reference electrodes were in good agreement each other as shown in Fig. 11 when they are compared at the same aluminum concentration level. This suggests that emf values measured in this study for both reference electrodes are approximately valid.

\subsection{Investigation of Ionic Transference Number}

It is necessary to investigate the ionic transference number in the solid electrolyte considering that measurements were carried out in $\mathrm{Zn}-\mathrm{Al}$ baths where the temperature and oxygen pressure was extremely low. Therefore, the ionic transference number in the stabilized zirconia solid electrolyte was estimated by the following equation given by Iwase et ll. $^{13)}$

$\log \left(P_{\Theta} / \mathrm{Pa}\right)-\log (101325)=18.08-6.24 \times 10^{4} / T$

(for $8 \mathrm{~mol} \% \mathrm{Y}_{2} \mathrm{O}_{3}$ stabilized $\mathrm{ZrO}_{2}$ )

Substitution of $T / \mathrm{K}=773$ into Eq. (10) gives Eq. (11).

$$
P_{\ominus} / \mathrm{Pa}=2.3 \times 10^{-58}
$$

According to the reports of Schmalzried, ${ }^{14,15)}$ the emf of solid electrolyte cell $E^{*}$ considering not only ionic but also n-type electronic conduction is represented by Eq. (12).

$$
E^{*}=\frac{R T}{F}\left(\ln \frac{P \dot{h}^{1 / 4}+P_{\mathrm{O}_{2}}(\mathrm{I})^{1 / 4}}{P \dot{h}^{1 / 4}+P_{\mathrm{O}_{2}}(\mathrm{II})^{1 / 4}}+\ln \frac{P_{\ominus}^{1 / 4}+P_{\mathrm{O}_{2}}(\mathrm{II})^{1 / 4}}{P_{\Theta}^{1 / 4}+P_{\mathrm{O}_{2}}(\mathrm{I})^{1 / 4}}\right)
$$

where $P_{\ominus}$ represents $P_{\mathrm{O}_{2}}$ at which the degree of electronic conduction is equal to that of ionic conduction and $P \dot{h}$ represents $P_{\mathrm{O}_{2}}$ at which the degree of n-type electronic conduction is equal to that of ionic conduction. We can neglect the first term in the parentheses of right side of Eq. (12) because the oxygen pressure measured by the present cell construction is quite low.

In the case of $\mathrm{Zn}-\mathrm{Al}$ bath system, the partial oxygen pressure at the working electrode $P_{\mathrm{O}_{2}}$ (II) is calculated by substituting the value of $P_{\Theta}$ given by Eq. (11), the measured cell emf $E^{*}$ and the oxygen pressure at the reference electrode into Eq. (12).

$$
P_{\mathrm{O}_{2}}(\mathrm{II}) / \mathrm{Pa}=1.048 \times 10^{-35}
$$

On the other hand, when calculating the value of $P_{\mathrm{O}_{2}}$ (II) directly from Eq. (2), it becomes as follows.

$$
P_{\mathrm{O}_{2}}(\mathrm{II}) / \mathrm{Pa}=1.048 \times 10^{-35}
$$

It is obvious that $P_{\mathrm{O}_{2}}$ (II) given by Eq. (13) is almost equal to that given by Eq. (14). This agreement suggests that the effect of electronic conduction on the cell emf is negligibly small assuming that the value of $P_{\ominus}$ measured at high temperature is applicable to the mea- surement at low temperatures.

\subsection{EMF Measurements in $\mathrm{Zn}-\mathrm{Mn}$ or $\mathrm{Zn}-\mathrm{Cr}$ Baths}

Ellingham diagram on oxide shows that pure manganese or chromium acts as a deoxidizer for molten zinc. Therefore, the effect of these additives on the oxygen pressure in molten zinc was investigated by emf measurements using the same combinations of zirconia solid electrolyte and reference electrode.

As a preliminary experiment, variations in the manganese or chromium concentration in the bath melted in the air atmosphere were examined and the variations were found to be so small that they could be ignored during one measurement.

Examples of the emf curve in the case of $\mathrm{Zn}-\mathrm{Mn}$ baths are shown in Fig. 12. The cells in this case respond quickly and show comparatively stable emfs which increase linearly with an increase in the logarithm of manganese concentration as shown in Fig. 13. In the case of chromium addition, the response of cell is quick and its stability is good as shown in Fig. 14.

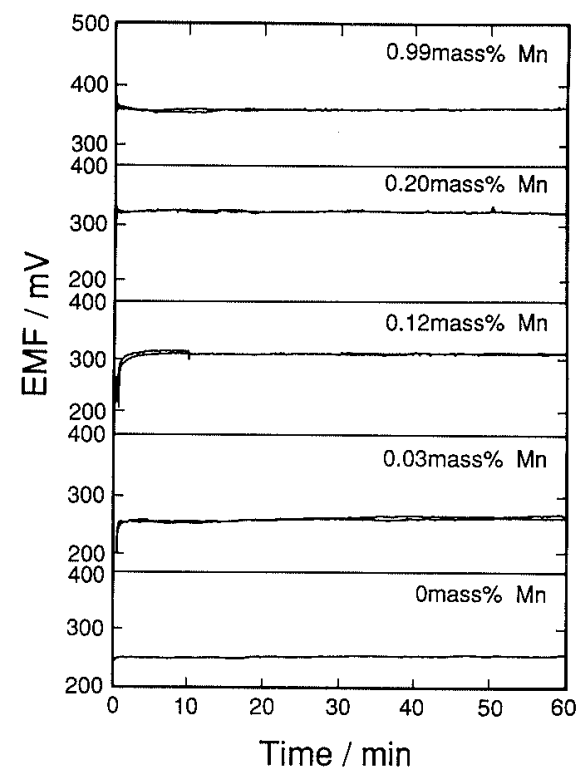

Fig. 12. Example of the emf curve of cell: $(-) \mathrm{W} \mid \underline{\mathrm{O}}$ in $(\mathrm{Zn}-$ $\mathrm{Mn})\left|\mathrm{ZrO}_{2}+8 \mathrm{~mol} \% \mathrm{Y}_{2} \mathrm{O}_{3}\right| \mathrm{In}, \mathrm{In}_{2} \mathrm{O}_{3} \mid \mathrm{W}(+)$.

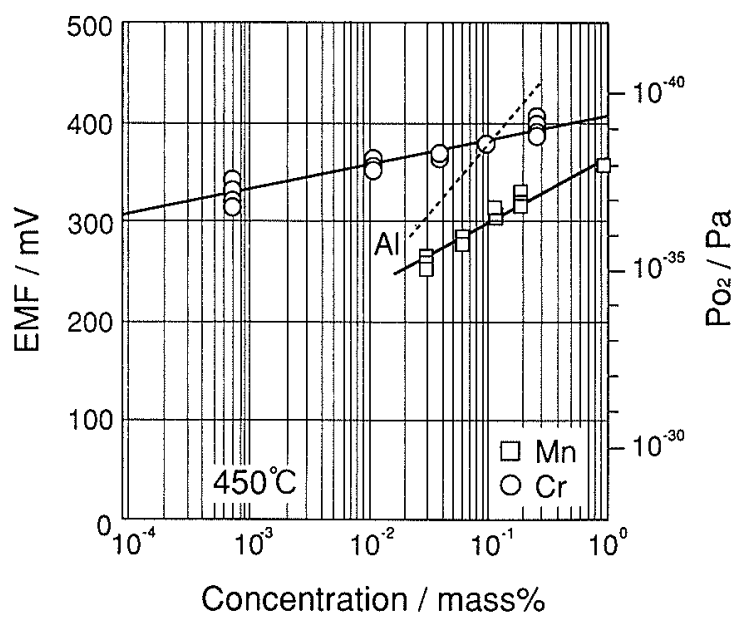

Fig. 13. Relationship between additive concentration in molten zinc and steady cell emf and oxygen potential of the bath. 


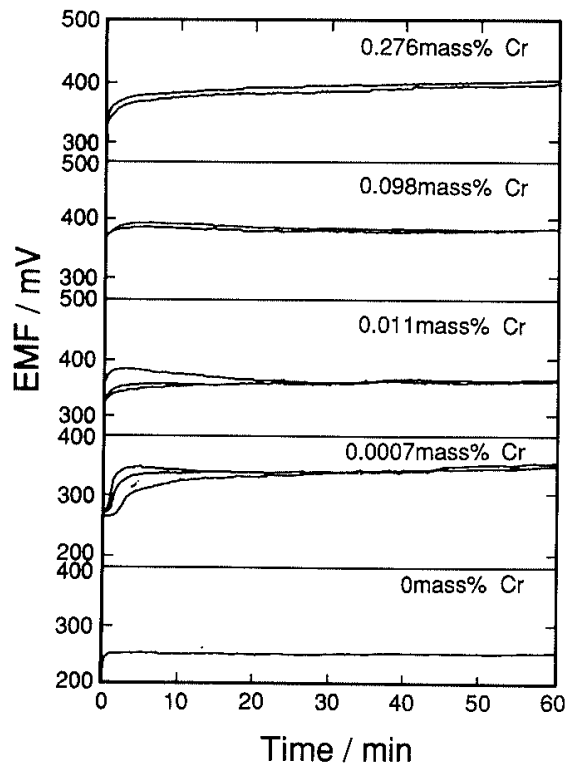

Fig. 14. Example of the emf curve of cell: $(-) \mathrm{W} \mid \mathrm{O}$ in $(\mathrm{Zn}-$ $\mathrm{Cr})\left|\mathrm{ZrO}_{2}+8 \mathrm{~mol} \% \mathrm{Y}_{2} \mathrm{O}_{3}\right| \mathrm{In}_{1} \mathrm{In}_{2} \mathrm{O}_{3} \mid \mathrm{W}(+)$.

The oxygen pressure calculated from the measured emf were the order of $10^{-40} \mathrm{~Pa}$, the same level as the case of $\mathrm{Zn}-\mathrm{Al}$ bath. These results show that the steady emf can be obtained by the present zirconia oxygen sensor down to about $10^{-40} \mathrm{~Pa}$. Therefore, the phenomenon that the cell emf gradually decreases after keeping contemporally stable value in the case of $\mathrm{Zn}-\mathrm{Al}$ bath is not due to the electronic conduction in the solid electrolyte. Any detailed study on this point has not been done. Hence, no reliable data to explain this phenomenon have been found.

\section{Conclusions}

As a means for in situ measurement of aluminum concentration in a hot dip galvanizing bath, a sensor based on the emf method using the zirconia solid electrolyte has been devised by utilizing the following equilibrium relation $\mathrm{Al}_{2} \mathrm{O}_{3}$ (s) $=2 \mathrm{Al}$ (in $\mathrm{Zn}$ ) $+3 \underline{\underline{O}}$ (in $\mathrm{Zn}$ ). The emf measurements were carried out in $\mathrm{Zn}-\mathrm{O}$, $\mathrm{Zn}-\mathrm{Al}-\mathrm{O}$ and $\mathrm{Zn}-\mathrm{Me}-\mathrm{O}(\mathrm{Me} ; \mathrm{Mn}$ or $\mathrm{Cr}$ ) baths and the following conclusions were obtained.

(1) From the emf measurements in $\mathrm{Zn}-\mathrm{O}$ bath, the following cell constructions (-)W|O (in $\mathrm{Zn}$ ) $\mid \mathrm{ZrO}_{2}+$ $8 \mathrm{~mol} \% \mathrm{Y}_{2} \mathrm{O}_{3} \mid \mathrm{In}-\mathrm{In}_{2} \mathrm{O}_{3}$ or $\mathrm{Zn}-\mathrm{ZnO} \mid \mathrm{W}(+)$ were found to be optimum for measuring the oxygen potential of the bath. The emf measured with these cells agreed fairly well with the extrapolated values from the thermo- dynamic data measured at higher temperatures.

(2) The use of these optimum cells in the $\mathrm{Zn}-\mathrm{Al}-\mathrm{O}$ bath enables the stable emf measurements when the aluminum concentration in the bath is less than 0.3 mass \%. The least mean squares regression analysis of the emf data showed that the cell emf linearly increases with an increase in the logarithm of aluminum concentration as shown below.

$$
\begin{gathered}
\text { In, } \mathrm{In}_{2} \mathrm{O}_{3}: E / \mathrm{mV}=57.19 \ln [\mathrm{Al}] / \mathrm{mass} \%+506.4, \\
0.02 \leqq[\mathrm{Al}] / \mathrm{mass} \% \leqq 0.3, \quad 450^{\circ} \mathrm{C} \\
\mathrm{Zn}, \mathrm{ZnO}: E / \mathrm{mV}=68.27 \ln [\mathrm{Al}] / \mathrm{mass} \%+270.4, \\
0.05 \leqq[\mathrm{Al}] / \mathrm{mass} \% \leqq 0.2, \quad 500^{\circ} \mathrm{C}
\end{gathered}
$$

Thus, the possibility of the present aluminum sensor has been ascertained experimentally.

(3) The external AC voltage of sine wave applied on the sensor immediately after immersion into the bath was found to be effective to improve the initial response and stability of the sensor.

(4) It was confirmed by calculating the value of $P_{\ominus}$ that the portion of electronic conduction in the zirconia solid electrolyte used in this study was negligibly small.

(5) The emf measurements in $\mathrm{Zn}-\mathrm{Mn}-\mathrm{O}$ or $\mathrm{Zn}-\mathrm{Cr}-\mathrm{O}$ baths suggest that the present emf method using zirconia solid electrolyte is applicable down to $P_{\mathrm{O}_{2}} / \mathrm{Pa}=10^{-40}$ at $450^{\circ} \mathrm{C}$.

\section{REFERENCES}

1) H. Yamaguchi and T. Hisamatsu: Tetsu-to-Hagané, 59 (1973), 131.

2) T. Ikeda, H. Okada, Y. Suemune and K. Kawaguchi: CAMPISIJ, 4 (1991), 663.

3) T. Nakamori, T. Toki and K. Abe: CAMP-ISIJ, 3 (1990), 1576.

4) K. Goto: Tetsu-to-Hagané, 62 (1976), 1265.

5) K. Nagata and K. Goto: Tetsu-to-Hagané, 67 (1981), 1899.

6) I. Katayama and Z. Kozuka: Bull. Jpn. Inst. Met., 24 (1985), 630.

7) I. Katayama and Z. Kozuka: Bull. Jpn. Inst. Met., 25 (1986), 528.

8) M. Iwase: Tetsu-to-Hagané, 75 (1989), 379.

9) For ex., R. J. Fruehan: Metall. Trans., 1 (1970), 3403.

10) For ex., D. Janke and W. A. Fischer: Arch. Eisenhüttenwes., 46 (1975), 297.

11) R. A. Rapp: Physicochemical Measurements in Metals Research, Part 2, Chap. 6C, Interscience Publ., New York, (1970), 123.

12) I. Katayama, A. Iseda, N. Kemori and Z. Kozuka: Trans. Jpn. Inst. Met., 23 (1982), 556.

13) M. Iwase, E. Ichise, M. Takeuchi and T. Yamasaki: Trans. Jpn. Inst. Met., 25 (1984), 43.

14) H. Schmalzried: Z. Phys. Chem., 38 (1963), 87.

15) H. Schmalzried: Ber. Bunsenges. Phys. Chem., 66, (1962), 572.

(Originally published in Tetsu-to-Hagané, 79 (1993), 180 and 955, in Japanese.) 